\title{
PROBLEMATIKA PEMBELAJARAN AL-QUR'AN HADIS DI MADRASAH TSANAWIYAH NEGERI (MTSN) 1 KOLAKA
}

\author{
ST. Normah Ali \\ MTs Negeri 1 Kolaka \\ Email:bamskonsel@gmail.com
}

\begin{abstract}
Abstrak
Penelitian ini bertujuan untuk mengetahui problematika pembelajaran Al-Qur'an Hadis dan mengetahui solusi dalam mengatasi problematika pembelajaran Al-Qur'an Hadis di MTsN 1 Kolaka. Hasil penelitian menunjukan bahwa problematika yang ada dalam pembelajaran Al-Qur'an Hadis di MTsN 1 Kolaka diantaranya adalah siswa kurang mampu dalam membaca Al-Qur'an sesuai dengan kaidah ilmu tajwid karena latar belakang lulusan siswa yang heterogen, belum diadakan penataran bagi guru AlQur'an Hadis dan sarana/ alat pembelajaran yang masih terbatas. Solusi untuk mengatasi problematika pembelajaran Al-Qur'an Hadis di MTsN 1 Kolaka diantaranya adalah dengan mengadakan kebijakan program Qur'anisasi artinya berusaha menciptakan madrasah yang Qur'ani seperti pada kegiatan Qiroati dan tadarus bagi seluruh siswa, diadakan diklat cara membaca dan mengajarkan Al-Qur'an dengan baik dan benar, serta pihak sekolah telah memprogramkan penambahan perangkat/sarana dan prasarana pembelajaran.
\end{abstract}

Kata Kunci: Problematic dan pembelajaran al-Quran Hadis

\begin{abstract}
This research aims to know the problem of learning the Al-Qur'an Hadis and find out the solutions to overcome the problems of learning the Qur'an Hadith in MTsN 1 Kolaka. This shows that the problematic in learning of Al-Qur'an Hadis at Islamic Junior Hight School 1 Kolaka are less able students in reading Al-Qur'an in accordance with the rule of science of tajwid because the background of graduate of heterogeneous students, not yet held upgrading for the teacher of Al-Qur'an hadis and the tools/learning facilities are still limited. The solution to solve the problematic learning of Al'Quran hadis at Islamic Junior Hight School 1 Kolaka is conduct a policy of Qur'anisasi program means trying to create madrasah Qur'ani as in Qiroati and tadarus activities for all students, held the training on how to read and teach the Al-Qur'an properly and correctly, and the school has programmed the addition of learning tools/learning facilities and infrastructure.
\end{abstract}

Keywords: problematic, \& learning Al-Qur'an Hadis 


\section{Pendahuluan}

Pendidikan merupakan kebutuhan yang tidak dapat dipisahkan dari kehidupan manusia. Pendidikan merupakan usaha sadar untuk menyiapkan peserta didik agar dapat berperan aktif dan positif dalam hidupnya sekarang dan yang akan datang. ${ }^{1}$ Pendidikan pada dasarnya merupakan interaksi antara pendidik dengan peserta didik, untuk mencapai tujuan pendidikan yang berlangsung dalam lingkungan tertentu. Interaksi ini dikenal dengan interaksi pendidikan yaitu saling pengaruh antara pendidik dengan peserta didik. Dalam interaksi tersebut peranan pendidik lebih besar karena kedudukannya sebagai orang yang dewasa lebih berpengalaman, lebih banyak menguasai nilai-nilai, pengetahuan dan keterampilan. ${ }^{2}$

Pendidikan merupakan salah satu media yang digunakan manusia untuk mengembangkan potensi dan mencapai yang diharapkan oleh manusia. untuk itu pendidikan dari masa ke masa melakukan perubahan berbagai aspek yang berkaitan dengan pendidikan, mulai dari materi pelajaran, metode, sarana dan prasarana perlu ditata ulang untuk di sesuaikan dengan tuntutan zaman reformasi ini perlu dilakukan jika dunia pendidikan ingin tetap bertahan secara fungsional dalam memadu perjalanan umat manusia. ${ }^{3}$

Di dalam undang-undang nomor 20 tahun 2003 tentang sistem pendidikan nasional nampak jelas bahwa pengertian pendidikan yaitu usaha sadar dan terencana untuk mewujudkan suasana belajar dan proses pembelajaran agar peserta didik secara aktif mengembangkan potensi dirinya untuk memiliki kekuatan spiritual, keagamaan, pengendalian diri, kecerdasan ahlak mulia, serta keterampilan yang diperlukan dirinya, masyarakat, bangsa dan Negara. ${ }^{4}$ Ada dua unsur dalam proses belajar mengajar yang sangat penting dimiliki oleh seorang guru, yaitu metode mengajar dan media

\footnotetext{
${ }^{1}$ Umar Tirtarahardja dan S.L. La Sulo, Pengantar Pendidikan, (Jakarta: Rineka Cipta, 2008), h. 263.

${ }^{2}$ Nana Syaodih Sukmadinata, Landasan Psikologis Proses Pendidikan, (Bandung: Rosdakarya, 2005), h. 3.

${ }^{3}$ Tilaar, Beberapa Agenda Reformasi Pendidikan Nasional, (Jakarta: Tera Indonesia, 2001), h.1.

${ }^{4}$ Pemerintah RI, Undang-Undang Republik Indonesia No. 20 Tahun 2003, Sistem Pendidikan Nasional, (Jakarta: Sinar Grafika: 2003), h. 3
} 
pembelajaran. Kedua aspek itu saling berkaitan, pemilihan salah satu metode pengajar tentu akan mempengaruhi jenis media yang sesuai. ${ }^{5}$

Sebagaimana yang diungkapkan Oemar H. Malik dalam bukunya "pendidikan guru berdasarkan pendekatan kompetensi" proses belajar dan hasil belajar para siswa bukan saja hanya ditentukan oleh sekolah, pola, struktur, dan isi kurikulum, akan tetapi sebagian ditentukan oleh kompetensi guru yang mengajar mereka. Guru yang kompetensi akan lebih mampu menciptakan lingkungan belajar yang efektif, sehingga belajar para siswa berada dalam tingkat optimal. ${ }^{6}$ Guru menyadari bahwa dalam tugas pembelajaran ternyata ada masalah-masalah belajar yang dialami oleh siswa bahkan guru memahami bahwa kondisi lingkungan siswa juga dapat menjadi sumber timbulnya masalah-masalah belajar. ${ }^{7}$ Salah satu kelemahan proses pembelajaran yang dilaksanakan para guru kita adalah kurang adanya usaha pengembangan berpikir siswa dalam setiap proses pembelajaran, pada mata pelajaran apapun guru lebih banyak mendorong agar siswa dapat menguasai sejumlah materi pelajaran, model pembelajaran diharapkan dapat meningkatkan kemampuan berpikir siswa. ${ }^{8}$

Hal-hal tersebut di atas, merupakan kendala-kendala yang dirasakan oleh guru pada umumnya dan juga berbagai macam problematika yang dihadapinya, tapi yang paling mendasar adalah kurangnya fasilitas untuk menyampaikan mata pelajaran terutama pada mata pelajaran agama Islam. Media pendidikan yang digunakan dalam proses belajar mengajar dapat mempertinggi proses belajar siswa dalam pengajaran yang pada gilirannya dapat mempertinggi hasil belajar yang dicapai. ${ }^{9}$ Oleh karena itu, tugas dan tanggung jawab seorang guru adalah mengelola pengajaran agar lebih efektif, dinamis, efisien dan positif. Dasar dari adanya kompetensi guru ini penulis nukilkan firman Allah SWT. Dalam Q.S Al-An'am (ayat: 135) sebagai berikut :

${ }^{5}$ Khaeruddin, Ilmu Pendidikan Islam, (Makassar : Yayasan Fabiah), 2002, h. 85

6 Oemar.H.Malik, Pendidikan Guru Berdasarkan Pendekatan Kompetensi, (Bandung: Bumi Aksara), 2002, h. 36.

${ }^{7}$ Dimyati dan Mujiono, Belajar dan Pembelajaran, (Jakarta: Rineka Cipta, 2006), h. 235.

${ }^{8}$ Wina Sanjaya, Pembelajaran dalam Implementasi Kurikulum Berbasis Kompetensi, (Jakarta: Kencana, 2006), h.

${ }^{9}$ Harjanto, Perencanaan Pengajaran, Jakarta: PT. Bineka Cipta, 2001, h. 243 


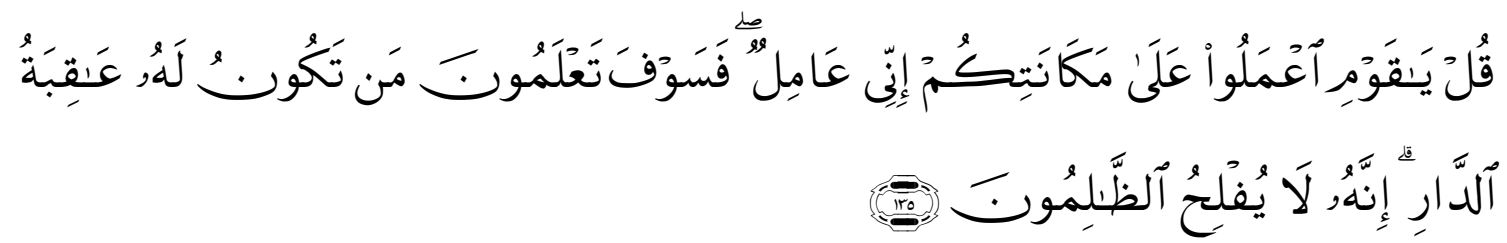

Terjemahanya:

"Katakanlah: Hai kaumku, berbuatlah sepenuh kemampuanmu, Sesungguhnya akupun berbuat (pula). Kelak kamu akan mengetahui, siapakah (diantara kita) yang akan memperoleh hasil yang baik di dunia ini. Sesungguhnya orang-orang yang zalim itu tidak akan mendapatkan keberuntungan."10

Berdasarkan ayat di atas, kompetensi merupakan suatu kemampuan yang mutlak dimiliki guru agar tugasnya sebagai pendidik dapat telaksana dengan baik, sebab dalam mengelola proses belajar mengajar yang dilaksanakan guru tidak memiliki kompetensi, maka akan sulit untuk mencapai tujuan pembelajaran yang diinginkan.

Didalam satuan pendidikan, Mata Pelajaran Al-Qur'an Hadis adalah salah satu pelajaran berciri khas Agama Islam yang memiliki tingkat kesulitan cukup tinggi, pada hal Al-Qur'an Hadis merupakan pokok pelajaran terpenting dalam rangka memasuki gerbang pengetahuan keislaman, Al-Qur'an Hadis begitu penting baik sebagai pegangan dan pedoman dalam berbuat, maka di Madrasah diadakan pendidikan Al-Qur'an Hadis agar generasi penerus tidak salah langkah. Sesuai firman Allah dalam Q.S Al-Baqarah (ayat 2) :

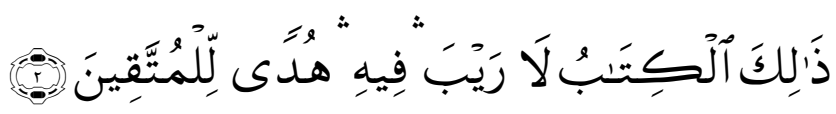

Terjemahanya:

Kitab itu (Al Qur'an) tidak ada keraguan padanya jadi petunjuk bagi mereka yang bertaqwa. ${ }^{11}$

Dalam Al-Qur'an dan Hadis dijelaskan bahwa untuk memperoleh kebahagiaan dan keselamatan dunia akhirat maka harus kembali pada Al-Qur'an Hadis. Sebagaimana firman Allah, dalam surat An-Nisa' ayat 59:

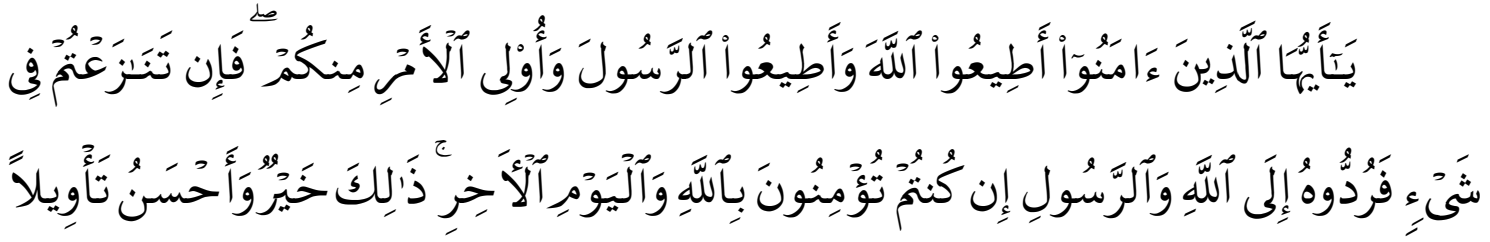

${ }^{10}$ Departemen Agama RI, Al-Qur'an dan Terjemahan, Jakarta: CV. Darus Sunnah, 2010, h. 146

11 Depag RI, Al-Qur'an dan Terjemah, (Semarang: Toha Putra, 2002), h. 2 
Terjemahanya:

"Hai orang-orang yang beriman, taatilah Allah dan taatilah Rasulnya dan ulil amri diantara kamu, kemudian jika kamu berlainan pendapat tentang sesuatu, maka kembalilah ia kepada Allah (Al-Qur'an) dan rasul (sunnah nya) jika karena benar-benar beriman kepada Allah dan hari kemudian. Yang demikian itu lebih utama (bagimu) dan lebih baik akibatnya". ${ }^{2}$

Pembelajaran Al-Qur'an Hadis yang merupakan bagian dari pendidikan agama Islam turut memberikan sumbangan tercapainya pendidikan nasional. Tugas pendidik tidak hanya menuangkan sejumlah informasi kedalam diri siswa, tetapi mengusahakan bagaimana agar konsep-konsep penting dan sangat berguna tertanam kuat dalam benak siswa. Bagi siswa, untuk benar-benar mengerti dan menerapkan ilmu pengetahuan, mereka harus bekerja untuk memecahkan masalah, menemukan ilmu, dan selalu bergulat dengan ide-ide, sehingga siswa akan selalu aktif dalam proses pembelajaran.

Hampir semua pokok bahasan PAI di sekolah memuat ayat-ayat Al-Qur'an. Tetapi, kenyataannya ada beberapa siswa yang mengalami kesulitan dalam membaca AlQur'an dengan baik dan benar, kurang bisa menerapkan tajwid dan bacaan dari ayat Al-Qur'an tersebut, bahkan ada siswa yang masih sangat awam terhadap ayat-ayat AlQur'an. ${ }^{13}$ Pada dasarnya peserta didik adalah individu yang unik, yang mempunyai kesiapan dan kemampuan fisik, psikis serta intelektual yang berbeda satu sama lainnya. Demikian pula halnya dalam proses belajar mengajar, setiap siswa mempunyai karakteristik yang berbeda. ${ }^{14}$

Keaktifan peserta didik dalam pembelajaran dapat merangsang dan mengembangkan bakat yang dimilikinya, berfikir kritis dan dapat memecahkan berbagai permasalahan dalam kehidupan. Untuk dapat mengaktifkan peserta didik. Pengajar dapat merekayasa pembelajaran secara sistematis, sehingga merangsang keaktifan peserta didik dalam pembelajaran. ${ }^{15}$ Oleh sebab itu dalam pembelajaran guru sebaiknya menggunakan suatu strategi pembelajaran yang membuat peserta didik banyak beraktivitas. Proses mempelajari sesuatu yang baru akan lebih efektif jika siswa itu aktif, mencari pola daripada menerima saja. Salah satu cara untuk membuat siswa belajar

12 Depag RI, Al-Qur'an dan Terjemah...., h. 114.

${ }^{13}$ Ahsin W. Al-Hafidz, Bimbingan Praktis Menghafal Al-Qur'an, Jakarta, Bumi Aksara, 1994, h. 97

${ }^{14}$ Hallen A., Bimbingan dan Konseling, Jakarta: Ciputat Press, 2002, h. 123-124.

${ }^{15}$ Martinis Yamin dan Bansu I. Ansari, Taktik Mengembangkan Kemampuan Individual Siswa, Jakarta: Gaung Persada Press, 2009, h.77 
secara aktif adalah dengan membuat mereka bertanya tentang materi pelajaran sebelum ada penjelasan dari guru. ${ }^{16}$

Pembelajaran Al-Qur'an Hadis yang dilaksanakan di MTsN 1 Kolaka tidak terlepas dari masalah dan hambatan, baik yang datang dari siswa itu sendiri maupun faktor-faktor lain. Masalah yang muncul dari siswa MTsN 1 Kolaka saat belajar AlQur'an Hadis adalah kurangnya minat dan perhatian siswa terhadap pelajaran Al-Qur'an Hadis sehingga siswa kurang menguasai mata pelajaran tersebut dan dampaknya siswa akan kesulitan untuk memahami pelajaran Al-Qur'an Hadis. Faktor lainnya adalah lingkungan keluarga yang tidak mengaplikasikan nilai-nilai Al-Qur'an Hadis dalam kehidupan sehari-hari. ${ }^{17}$

Sehubungan dengan uraian di atas, maka peneliti tertarik untuk menelusuri upaya mengatasi kesulitan-kesulitan yang pada umumnya dihadapi oleh siswa itu sendiri dalam pembelajaran Al-Qur'an Hadis dan guru dalam menyampaikan mata pelajaran Al-Qur'an Hadis, untuk maksud tersebut maka penelitian ini mengambil judul "Problematika Pembelajaran Al-Qur'an Hadis di MTsN 1 Kolaka". Pengelolaan pembelajaran yang baik dalam proses pembelajaran, diharapkan guru akan dapat memberikan konsentrasi pada siswa. Artinya guru dalam menyampaikan materi harus dapat memahami kondisi dan situasi kelas agar siswa benar-benar memperhatikan guru dalam menyampaikan materi dengan baik. Sebagaimana yang ada di MTsN 1 Kolaka terdapat pembelajaran Qur'an Hadis, di mana pembelajarannya terdapat problematika, seperti masih sulitnya siswa dalam menghafal, membaca, dan menulis Qur'an Hadis, dikarenakan latar belakang lulusan pendidikan siswa yang berbeda-beda, artinya ada siswa yang lulus dari sekolah dasar ada juga siswa yang lulus dari Madrasah Ibtidaiyyah. Sebab pembelajaran merupakan bagian atau elemen yang memiliki peran sangat dominan untuk mewujudkan kualitas baik proses maupun lulusan (output) pendidikan. Untuk itu perlu adanya suatu proses interaksi edukatif tentang suatu bahan pengajaran dinyatakan berhasil apabila hasilnya memenuhi tujuan pembelajaran khusus bahan tersebut.

\footnotetext{
${ }^{16}$ Raisul Muttaqien, Active Learning 1001 Cara Belajar Siswa Aktif, Bandung: Nusamedia, 2006, h. 157.

${ }^{17}$ Observasi Pendahuluan di Madrasah Tsanawiyah Negeri 1 Kolaka, pada Tanggal 3 Oktober 2017
} 
Penelitian ini dilaksanakan di Madrasah Tsanawiyah Negeri (MTsN) 1 Kolaka dengan menggunakan pendekatan kualitatif deskriptif. Tehnik pengambilan sampel dilakukan dengan metode purposive sampling yaitu informan kunci adalah kepala sekolah, guru Al-Qur'an hadis dan siswa selanjutnya menggunakan snowball sampling. Pengumpulan data menggunakan teknik observasi non partisipan, wawancara dan dokumentasi. Teknik analisis data menggunakan yaitu reduksi data, display data dan verifikasi data. Uji keabsahan data menggunakan perpanjangan pengamatan, peningkatan ketekunan dan triangulasi.

\section{Metode Penelitian}

Penelitian ini merupakan penelitian deskriptif kualitatif. Tehnik pengambilan sampel dilakukan dengan metode purposive sampling yaitu informan kunci adalah kepala sekolah, guru Al-Qur'an hadis dan siswa selanjutnya menggunakan snowball sampling. Pengumpulan data menggunakan teknik observasi non partisipan, wawancara dan dokumentasi. Teknik analisis data menggunakan yaitu reduksi data, display data dan verifikasi data. Uji keabsahan data menggunakan perpanjangan pengamatan, peningkatan ketekunan dan triangulasi.

\section{Problematika Pembelajaran}

Dalam Kamus Besar Bahasa Indonesia, problematika diartikan sama dengan permasalahan, yang berasal dari Bahasa Inggris "Problem" yaitu something that s difficult to deal with or understand. Maksudnya problem adalah suatu perkara yang membutuhkan pemikiran untuk menentukan penyelesaianya. Sedangkan, problematika merupakan kata sifat dari problem yang berati masalah yang merupakan sebuah persoalan. ${ }^{18}$

Kata "problem" berarti masalah, persoalan sedangkan kata "problematika" diartikan dengan suatu yang masih menimbulkan masalah atau masih belum dapat dikerjakan. ${ }^{19}$ Syukir mengemukakan problematika adalah suatu kesenjangan yang mana

\footnotetext{
${ }^{18}$ Tim Reality, Kamus Terbaru Bahasa Indonesia, (Surabaya: Reality Publisher, 2008), h. 600.

${ }^{19}$ Depdikbud, Kamus Besar Bahasa Indonesia, (Jakarta: Bulan Bintang, 2002), h. 789
} 
antara harapan dan kenyataan yang diharapkan dapat menyelesaikan atau dapat diperlukan. ${ }^{20}$

Jadi penulis dapat simpulkan bahwa problematika adalah berbagai persoalanpersoalan sulit yang dihadapi dalam proses pemberdayaan, baik yang datang dari faktor intern atau ekstern. Secara sederhana istilah pembelajaran sebagai upaya untuk membelajarkan seseorang atau kelompok orang melalui berbagai upaya (efforts) dan berbagai strategi, metode dan pendekatan kearah pencapaian tujuan yang telah direncanakan. Pembelajaran dapat juga dikatan sebagai kegiatan guru secara terprogram dalam desain intruksional untuk membuat peserta didik belajar secara aktif yang menekankan pada penyediaan sumber belajar. Dengan kata lain bahwa pembelajaran merupakan upaya membelajarkan peserta didik untuk belajar. Kegiatan ini mengakibatkan peserta didik mempelajari sesuatu dengan cara yang lebih efektif dan

\section{Pembelajaran Al-Qur'an Hadis}

Secara Bahasa Qara'a mempunyai arti mengumpulkan, atau menghimpun menjadi satu Kata Qur'an dan Qira'ah keduanya merupakan masdar (infinitif) diambil dari kata kerja lampau (Fi'il Madhi) yaitu. Qara'a- Qiraatan- Quranan. ${ }^{21}$ Ada beberapa pokok ajaran dalam isi kandungan Al-Qur'an diantaranya sebagai berikut :
a. Akidah
b. Ibadah dan Muamalah
c. Hukum
d. Akhlak
e. Kisah-kisah umat terdahulu. ${ }^{22}$

Tujuan adalah suatu yang diharapkan tercapai setelah sesuatu usaha atau kegiatan selesai, tujuan pendidikan bukanlah suatu benda terbentuk tetap dan statis, tetapi merupakan suatu keseluruhan dari kepribadian seseorang dengan seluruh aspek kehidupannya. $^{23}$ Tujuan pembelajaran adalah suatu pernyataan yang spesifik yang dinyatakan dalam perilaku atau penampilan yang diwujudkan dalam bentuk tulisan untuk

\footnotetext{
${ }^{20}$ Syukir, Dasar-dasar Strategi Dakwah Islami, (Surabaya: Al-Ikhlas, 1983), h. 65

${ }^{21}$ Muhaimin, Dimensi-Dimensi Studi Islam, (Surabaya: Karya Abditama, 1994), h. 86.

22 Sulaiman Abdullah, Sumber Hukum Islam, (Jambi: Sinar Grafika, 1998), h. 26

${ }^{23}$ Zakiyah Daradjat, Ilmu Pendidikan Islam, (Jakarta: Bumi Aksara, 2001), h. 29.
} 
menggambarkan hasil belajar yang diharapkan. ${ }^{24}$ Martinis Yamin, memandang bahwa tujuan pembelajaran merupakan sasaran yang hendak dicapai pada akhir pembelajaran, dan kemampuan yang harus dimiliki siswa. ${ }^{25}$ Dalam Permendiknas RI No. 52 Tahun 2008 tentang Standar Proses disebutkan bahwa tujuan pembelajaran memberikan petunjuk untuk memilih isi mata pelajaran, menata urutan topik-topik, mengalokasikan waktu, petunjuk dalam memilih alat-alat bantu pengajaran dan prosedur pengajaran, serta menyediakan ukuran (standar) untuk mengukur prestasi belajar siswa. ${ }^{26}$

Tujuan pembelajaran Qur'an Hadis dapat didefinisikan sebagai kualifikasi yang harus dimiliki oleh peserta didik setelah menyelesaikan kigiatan pembelajaran bidang studi Qur'an Hadis dalam suatu lembaga pendidikan. ${ }^{27}$

Sedangkan fungsi dari mata pelajaran Al-Qur'an Hadis pada madrasah memiliki fungsi sebagai berikut:

a. Pengembangan, yaitu meningkatkan keimanan dan ketaqwaan peserta didik dalam meyakini kebenaran ajaran Islam yang telah mulai dilaksanakan dalam lingkungan keluarga maupun jenjang pendidikan sebelumnya

b. Perbaikan, yaitu memperbaiki kesalahan-kesalahan dalam keyakinan, pemahaman, dan pengalaman ajaran islam peserta didik dalam kehidupan sehari-hari

c. Pencegahan, yaitu untuk menangkal hal-hal negatif dari lingkungan atau budaya lain yang dapat membahayakan diri peserta didik dan menghambat perkembangannya menuju manusia Indonesia seutuhnya yang beriman dan bertaqwa kepada Allah Swt

d. Pembiasaan, yaitu menjadikan nilai-nilai Al-Qur'an dan Hadis sebagai petunjuk dan pedoman bagi peserta didik dalam kehidupannya sehari-hari. ${ }^{28}$

\section{Kurikulum Pembelajaran Al-Qur'an Hadis}

Kurikulum adalah seperangkat rencana dan pengaturan mengenai tujuan, isi dan bahan pelajaran serta cara yang digunakan sebagai pedoman penyelenggaraan kegiatan pembelajaran untuk mencapai tujuan pendidikan tertentu. ${ }^{29}$ Dengan demikian dalam

${ }^{24}$ B.Uno, Hamzah, Perencanaan Pembelajaran, (Jakarta: Bumi Aksara, 2009), h. 35.

${ }^{25}$ Martinis Yamin, Profesionalisasi Guru dan Implementasi KTSP, (Jakarta: Gaung Persada Press, 2007), h. 133.

${ }^{26}$ B.Uno, Hamzah, Perencanaan Pembelajaran ...., h. 39 h. 108 .

${ }^{27}$ Wina Sanjaya, Kurikulum dan Pembelajaran, (Jakarta: Kencana Prenada Media Group, 2008),

${ }^{28}$ Departemen Agama, Standar Kompetensi, (Jakarta: Depag, 2004), h.5

29 Departemen Agama RI, Kurikulum Tingkat Satuan Pendidikan (KTSP) untuk Madrasah Ibtidaiyah, (Jakarta: Depag, 2006), h. 22. 
pengembangan kurikulum Al-Qur'an Hadis disusun antara lain agar dapat memberi kesempatan peserta didik untuk belajar untuk beriman dan bertakwa kepada Allah SWT, belajar untuk memahami dan menghayati, belajar untuk mampu melaksanakan dan berbuat secara efektif, belajar untuk hidup bersama dan berguna untuk orang lain, dan belajar untuk membangun dan menemukan jati diri melalui proses belajar yang aktif, kreatif, efektif dan menyenangkan. ${ }^{30}$

Selanjutnya pendidikan Al-Qur'an Hadis di Madrasah sebagai landasan yang integral dari pendidikan Agama, memang bukan satu-satunya faktor yang menentukan dalam pembentukan watak dan kepribadian peserta didik, tetapi secara substansial mata pelajaran Al-Qur'an Hadis memiliki kontribusi dalam memberikan motivasi kepada peserta didik untuk mempraktekkan nilai-nilai keyakinan kegamaan (tauhid) dan Ahlaqul karimah dalam kehidupan sehari-hari. ${ }^{31}$

\section{Problematika Pembelajaran Al-Qur'an Hadis}

Dalam Kamus Besar Bahasa Indonesia, problematika diartikan sama dengan permasalahan, yang berasal dari Bahasa Inggris "Problem" yaitu something that s difficult to deal with or understand. Maksudnya problem adalah suatu perkara yang membutuhkan pemikiran untuk menentukan penyelesaianya. Sedangkan, problematika merupakan kata sifat dari problem yang berati masalah yang merupakan sebuah persoalan. ${ }^{32}$

1. Hambatan yang bersifat linguistik

a. Problem membaca

Belajar membaca artinya belajar mengucapkan lambang-lambang bunyi tertulis baik dari Al-Qur'an dan hadis. Walaupun kegiatan ini nampaknya sederhana, tetapi bagi siswa pemula mungkin merupakan kegiatan yang cukup kompleks, karena harus melibatkan berbagai hal yaitu pendengaran, penglihatan, pengucapan disamping akal pikiran. Kedua hal terakhir ini bekerja secara mekanik dan simultan untuk melahirkan prilaku membaca. Ditambah lagi materi yang dibaca adalah rangkaian kata-kata Arab yang banyak berbeda sistem bunyi dan

\footnotetext{
${ }^{30}$ Departemen Agama RI, Kurikulum Tingkat Satuan Pendidikan..., h. 28

${ }^{31}$ Departemen Agama RI., Kurikulum 2006, Pedoman Umum Pengembangan Silabus Madrasah Ibtidaiyah, (Jakarta: Direktorat Jenderal Kelembagaan Agama Islam, 2006), h. 19.

32 Tim Reality, Kamus Terbaru Bahasa Indonesia, (Surabaya: Reality Publisher, 2008), h. 600.
} 
penulisanya dengan yang mereka kenal dengan bahasa ibu dan bahasa indonesia. ${ }^{33}$

b. Problem menulis

Belajar menulis huruf Latin dengan huruf Arab jelas berbeda, suku kata dan fonetiknya berbeda pula. Kesulitan yang sering dialami adalah menulis jika menulis Latin diawali dari kiri sedang menulis Arab dimulai dari sebelah kanan, mengabungkan huruf yang satu dengan yang lainya dalam kalimat, serta dalam memberi harakat. Adapun detailnya adalah sebagai berikut:

1) Menulis lebih sulit dari pada membaca dan menghafal

2) Menulis membutuhkan konsentrasi antara tangan, ingatan dan penglihatan.

c. Problem Menghafal

Menghafal Al-Qur'an dan Hadis boleh sebagai langkah awal untuk memahami kandungan Al-Qur'an Hadis. Hal ini tidaklah terlepas dari berbagai macam problem. Adapun problem yang yang dihadapi para penghafal Al-Qur'an itu secara garis besarnya adalah sebagai berikut:

1) Menghafal itu susah

2) Ayat-ayat yang sudah hafal lupa lagi

3) Banyaknya ayat-ayat yang serupa

4) Gangguan kejiwaan

5) Gangguan lingkungan

6) Banyaknya kesibukan dan lain-lain. ${ }^{34}$

d. Problem Menterjemah

Penerjemah harus menguasai bahasa sumber secara integral dan bidang kebahasaan dari bahasa yang diterjemahkan yaitu dia harus menguasai gramatikanya. Dalam bahasa Al-Qur'an Hadis sering dijumpai problematika tentang perbendaharaan kata, karena dalam Al- Qur'an dan Hadis banyak arti sehingga sulit untuk menentukan kata yang tepat yang sesuai dengan konteks kalimatnya, menyusun subyek, predikat, dan obyeknya. Hal itu dikarenakan dalam Al-Qur'an Hadis susunanaya berbeda dengan bahasa Indonesia.

e. Problem Memahami

\footnotetext{
${ }^{33}$ Depag RI, Metode-Metode Membaca Al-Qur'an Di Sekolah Umum, (Jakarta: Dirjen Pembinaan Kelembagaan Agama Islam, 1997), h. 24.

${ }^{34}$ Ahsin W. Al-Hafidz, Bimbingan Praktis Menghafal Al-Qur'an, (Jakarta: Bumi Aksara, 1994), h. 41
} 
Dalam Al-Qur'an dan Haidts untuk memahami dan memperoleh pengertian yang jelas tentang arti dan nilai-nilai yang terkandung didalam Al-Qur'an Hadis perlu mempekerjakan akal. Dan cara mempekerjakan akal adalah sangat dianjurkan, terutama jika membaca Al-Qur'an dan Hadis hendanya menggunakan pikiran, lalu berusaha berbuat menurut petunjuknya sehingga mencapai tujuan. Petunjuk illahi bagaimana cara perpikir yang baik sehingga dapat memahami dan menafsirkan Al-Qur'an Hadis secara benar. ${ }^{35}$

2. Hambatan yang bersifat non Linguistik

Adapun sebab-sebab kesulitan belajar Al-Qur'an Hadis yang bersifat non linguistik dapat digolongkan menjadi dua bagian yaitu :

a. Sebab-sebab endogen (dari dalam diri anak), diantara sebab-sebab ini adalah:

1) Sebab-sebab yang bersifat biologis yaitu yang berhubungan dengan jasmaniah

2) Sebab-sebab yang bersifat psikologis, yaitu sebab yang berhubungan dengan kejiwaan anak. ${ }^{36}$

b. Sebab-sebab eksogen (dari luar diri anak), diantaranya sebab-sebab ini terbagi menjadi tiga macam yaitu :

1) Faktor sekolah

2) Faktor keluarga

3) Faktor masyarakat. ${ }^{37}$

\section{Hasil dan Pembahasan}

Setiap proses pembelajaran tidak akan terlepas dari adanya problem/masalah yang bisa menghambat proses pembelajaran tersebut. Demikian juga dengan pembelajaran Al-Qur'an Hadits di MTsN 1 Kolaka masih terdapat bermacam-macam unsur yang menunjang maupun menghambat terhadap pembelajaran dalam usaha mencapai tujuan. Sejauh pengamatan penulis, problematika yang dihadapi baik itu yang datang dari sekolah maupun yang datang dari siswa. Adapun problem yang datang dari sekolah antaranya: tujuan pembelajaran, materi, metode, guru, alat pembelajaran maupun sumber belajar. Adapun yang selain itu, problem yang

${ }^{35}$ Ali Yasir, Metode Tafsir Alqur'an Praktis, (Yogyakarta: Yayasan PIRL, t.t), h. 53

54

${ }^{36}$ Slameto, Belajar \& Faktor-Faktor Yang Mempengaruhinya, (Jakarta: Rineka Cipta, 2003), h.

${ }^{37}$ Slameto, Belajar \& Faktor-Faktor Yang Mempengaruhinya ..., h. 60 
datangnya dari diri siswa itu sendiri. Salah satu yang menjadi problem dalam pembelajaran al-Quran hadis di MTs Negeri 1 Kolaka yaitu pertama materi. Materi yang disampaikan oleh guru kepada siswa pun mengalami masalah dalam penyampaiannya. Hal itu disebabkan bahwa banyak siswa yang belum memahami tajwid dengan baik. Oleh sebab itu waktu yang ada hanya habis untuk belajar membaca al-Quran yang seharusnya sudah pada tahap memahami. Selain itu guru tidak memberikan menjelaskan secara detail hukum bacaan al-Quran karena muatan pembelajaran bukan membaca al-Quran, akan tetapi kemampuan membaca perpengaruh kepada pemahaman anak anak pada materi yang diajarkan.

Kedua, masalah yang berasal dari siswa seperti faktor latar belakang pendidikan siswa. Hasil observasi peneliti kepada beberapa kelas VII dan VIII. Di kelas tersebut ditemukan ada beberapa siswa yang tidak bisa membaca al-Quran, misalnya Zulthan Zachky Al Imran dari kelas VII dan Hanzani Takwin dari kelas IX Peduli Lingkungan. Kedua siswa tersebut merupakan contoh tentang fakta bahwa anak yang belum mahir mengaji akan berdampak pada ayat atau hadis yang akan di hafal. Selain pendidikan factor latar belakang keluarga siswa. Problem dalam pembelajaran Al-Qur'an Hadis juga dipengaruhi oleh kurangnya perhatian dan dukungan dari orang tua terhadap anaknya. Sesungguhnya anak tidak hanya belajar di sekolah saja, akan tetapi juga di lingkungan keluarga dan masyarakat. Sebagaimana diketahui bahwa orang tua merupakan pendidik pertama bagi anaknya. Ketika orang tua menyerahkan pendidikan anaknya ke sekolah, orang tua bukannya lepas tangan begitu saja terhadap pendidikan anaknya, akan tetapi orang tua hendaknya selalu memantau dan memperhatikan pendidikannya ketika di rumah. Peran orang tua sangatlah penting dalam rangka belajar membaca Al-Qur'an dengan baik dan benar. Karena orang tua juga termasuk faktor yang ikut mempengaruhi belajar siswa. Orang tua yang menyadari betul akan pentingnya pendidikan akan selalu memperhatikan belajar anaknya, tetapi sebaliknya jika orang tua tidak menyadari akan pentingnya pendidikan bagi anaknya, maka mereka tidak akan pernah peduli dan memperhatikan belajar anak-anaknya.

Faktor selanjutnya adalah kemampuan siswa. Secara garis besarnya ada tiga tingkat kemampuan siswa dalam membaca Al-Qur'an di MTsN 1 Kolaka yang sangat berpengaruh terhadap pelaksanaan kegiatan belajar mengajar khususnya mata pelajaran Al-Qur'an Hadis. Kemampuan siswa sangat berpengaruh untuk tercapainya tujuan 
pembelajaran. Kemampuan siswa dalam hal berkaitan dengan kecerdasan dan kesehatan. Dari beberapa problematika yang dihadapi oleh MTsN 1 Kolaka khususnya dalam pembelajaran Al-Qur'an Hadis, maka ada kebijakan program untuk mengatasi problematika pembelajarn Al-Qur'an hadis artinya bahwa bagaimana berusaha menciptakan madrasah yang Qur'ani. Adapun kegiatannya antara yaitu:

Pertama, mengadakan diklat cara membaca Al-Qur'an dan cara mengajarkannya. Mengajar pada hakekatnya merupakan upaya guru dalam menciptakan situasi belajar yang harmonis dan menyenangkan, maka diharapkan mampu menumbuhkan berbagai kegiatan belajar mengajar, dengan perkataan lain proses belajar mengajar merupakan proses intraksi edukatif antara guru dengan siswa dengan menciptakan suasana belajar mengajar yang memberi respons terhadap usaha guru tersebut.Diklat ini dilaksanakan ketika liburan akhir tahun selama 3 minggu.

Berdasarkan hasil dokumentasi dapat dijelaskan bahwa ada beberapa kegiatan pengembangan kompetensi guru terkhusus mengajar dan cara mengajarkan al-Quran dengan mudah. Hal itu dapat dilihat pada tabel di bawah ini:

Tabel 1

Kegiatan Pengembangan Profesionalitas Guru MTs Negeri 1 Kolaka

\begin{tabular}{|l|l|l|l|l|}
\hline No & Tanggal & Bentuk Kegiatan & Penyelenggara & Peserta \\
\hline 1 & 22-24 Agustus 2017 & Diklat & $\begin{array}{l}\text { Kementerian } \\
\text { Agama }\end{array}$ & Darwisa \\
\hline 2 & $19-21$ April 2017 & Workshop & $\begin{array}{l}\text { Kementerian } \\
\text { Agama }\end{array}$ & $\begin{array}{l}\text { Sitti } \\
\text { Nurhaedah } \\
\text { Kattong }\end{array}$ \\
\hline
\end{tabular}

Sumber data: Kantor MTs Negeri 1 Kolaka

Kedua, menerapkan pembelajaran cara membaca Al-Qur'an bagi siswa baru. Khusus bagi siswa baru (kelas VII) diadakan kegiatan Qiroati/ membaca Al-Qur'an dengan baik dan benar selama 1 semester ( 6 bulan) dengan mengambil waktu pada pukul 06.30-07.15 WIB tepatnya sebelum KBM dimuali. Kegiatan ini dibimbing langsung oleh Wali kelas dan guru-guru yang kompeten di bidangnya. Setelah dinyatakan lulus Qiroati 1-6 dalam jangka waktu 1 semester tersebut, mereka dianjurkan untuk menghafal surat-surat pendek dan mengikuti pembelajaran tajwid. Sedangkan bagi yang belum lulus, nantinya akan ada penanganan khusus. Di MTs Negeri 1 Kolaka 
jika ditemukan siswa yang belum mahir membaca al-Quran maka sekolah menyediakan program TPA yang dilakukan dalam satu semester. Bagi siswa yang sudah dinyatakan lolos dalam program matrikulasi maka akan mendapat pengakuan secara resmi dalam bentuk sertifikat. Dari hasil observasi diketahui pula bahwa pada saat melaksanakan pembelajaran membaca al-Quran guru menggunakan pedekatan materi yang mudah dipahami. Adapun materi tersebut misalnya contoh idgam biguna dan idgam bilaguna. Jika idgam biguna (ي, ن, م) agar memudahkan siswa mengingatnya guru menyebutkannya dengan "YANMU” sedangkan igham bilaguna ( ) (llebih mudah guru menyembutnya dengan "LAMRA". Guru biasanya menyelipkan materi Tadjwid ditengah - tengah kegiatan membaca al-Quran.

Ketiga, melaksanakan tadarus Al-Qur'an. Berbeda dengan kelas VII (siswa baru), bagi siswa kelas VIII dan kelas IX melaksanakan tadarus Al-Qur'an di kelas masing-masing dengan mengambil waktu sebelum KBM berjalan yaitu pada pukul 07.00-07.15 WIB yang di bimbing langsung oleh guru mata pelajaran pada jam ke-1. Kegiatan tadarus ini dilaksanakan setiap hari kecuali pada hari Senin. Karena pada hari Senin digunakan untuk kegiatan Upacara dan kegiatan ekstrakurikuler yang lainnya.

Ketiga, pengadaan sumber belajar. Terkait dengan kurangnya sumber belajar sebagai sarana penunjang lancarnya proses pembelajaran dikelas seperti kurangnya buku-buku pegangan siswa dan buku-buku pengembangan yang lain (LKS). Di perpustakaan MTs Negeri 1 Kolaka bahwa ternyata ada tambahan buku baru al-Quran hadis terbetitan dari tiga serangkai. Seluruh buku berjumlah 300 buah dengan tingkatan kelas VII, VIII, dan IX. Sebelumnya buku al-Quran hadis hanya terbitan kementerian agama dengan jumlah terbatas. Adanya buku tambahan tersebut memberikan motivasi kepada siswa untuk lebih semangat dalam memperlajari al-Quran dan hadist. Keempat, memberikan pengarahan bagi siswa. Hampir setiap pagi guru agama dan guru yang lainnya memberikan motivasi. Selain yang dapat terkontrol karna ketika apel pagi dilaksanakana akan diketahui siswa yang terlambat atau tidak. Misalnya pada pagi itu guru yang memberikan pengarahan adalah bapak Hartono, S,Ag., MA. Adapun tema pengarahan adalah tentang semangat belajar mempersiapkan waktu ujian dengan baik.

Kelima, melakukan komunikasi kepada orang tua siswa. Dari pihak sekolah memberikan informasi kepada orang tua siswa dengan menyarankan agar ikut membantu 
dalam memperhatikan anaknya di rumah masing-masing, terutama dalam pendidikan agama dan khususnya mengenai belajar membaca dan menulis huruf Al-Qur'an. Dengan demikian diharapkan anak-anak sudah mempunyai bekal dari rumah dan nantinya dikembangkan di madrasah. Keenam, penagadaan Sarana dan Prasarana. Untuk mengatasi masalah pembelajaran al-Qur'an hadis tentunya harus menyelesaikan berbagai akar persoalan yang telah terjadi. Misalnya, yang saat ini sedang dihadapi guru dan siswa dalam pembelajaran al-Quran Hadis adalah keterbatasan media seperti LCD. Dari masalah tersebut, maka penjabaran materi yang seharusnya mudah akan menjadi susah untuk dijelaskan secara mendetail. Berikaitan tentang masalah tersebut tentunya madrasah telah melakukan pengadaan LCD secara bertahap.

\section{Penutup}

Problematika yang ada dalam pembelajaran Al-Qur'an Hadis di MTsN 1 Kolaka diantaranya adalah siswa kurang mampu dalam membaca Al-Qur'an sesuai dengan kaidah ilmu tajwid karena latar belakang lulusan siswa yang heterogen, belum diadakan penataran bagi guru Al-Qur'an Hadis dan sarana/alat pembelajaran yang masih terbatas. Solusi untuk mengatasi problematika pembelajaran Al-Qur'an Hadis di MTsN 1 Kolaka diantaranya adalah dengan mengadakan kebijakan program Qur'anisasi. Adapun program tersebut diantaranya adalah mengadakan diklat cara membaca AlQur'an dan cara mengajarkannya, menerapkan pembelajaran cara membaca Al-Qur'an bagi siswa baru, melaksanakan tadarus Al-Qur'an, pengadaan Sumber Belajar, memberikan pengarahan bagi siswa dan membangun komunikasi dengan orang tua siswa.

\section{DAFTAR PUSTAKA}

Aan Komariah \& Cepi Triatna, Visionary Leadership Menuju Sekolah Efektif, Jakarta: Bumi Aksara, 2006.

Abdul Majid, Perencanaan Pembelajaran Mengembangkan Kopetensi Guru, Bandung: Remaja Rosdakarya: 2008.

Abdul Majid, Strategi Pembelajaran, Bandung: Ros dakarya, 2014.

Ahsin W. Al-Hafidz, Bimbingan Praktis Menghafal Al-Qur'an, Jakarta, Bumi Aksara, 1994. 
Ahmad Sabri, Stategi Belajar Mengajar: Micro Teaching, Jakarta: Quantum Teaching, 2005Akyas Azhari, Psikologi Pendidikan, Semarang : Dina Utama Semarang, 1996.

Ali yasir, Metode Tafsir Alqur'an Praktis, Yogyakarta: Yayasan PIRL, t.t.Aunurrahman, Belajar dan Pembelajaran, Bandung: Al-Fabeta, 2009.

B.Uno, Hamzah, Perencanaan Pembelajaran, Cet. V, Jakarta: Bumi Aksara, 2009.

Cece Wijaya dan A. Tabrani Rusyan, Kemampuan Dasar Guru dalam Proses Belajar Mengajar, Bandung:Rasda Karya, 1991.

Dimyati dan Mudjiono, Belajar dan Pembelajaran, Jakarta: Rineka Cipta, 2009.

Depag RI, Al-Qur'an dan Terjemah, Semarang : Toha Putra, 2002.

Debdikbud, Kamus Besar Bahasa Indonesia, Jakarta : Bulan Bintang, 2002.

Dimyati dan Mujiono, Belajar dan Pembelajaran, Jakarta : Rineka Cipta, 2006. , Belajar dan Pembelajaran, Jakarta: Rineka Cipta, 2010.

Departemen Agama, Standar Kompetensi, Jakarta: Bumi Aksara, 2004.

Depag RI, Metode-Metode Membaca Al-Qur'an Di Sekolah Umum, Jakarta: Dirjen Pembinaan Kelembagaan Agama Islam, 1997.

Departemen Agama, Standar Kompetensi, Jakarta: 2004.

Debdikbud, Kamus Besar Bahasa Indonesia, Jakarta : Bulan Bintang, 2002.

Departemen Agama RI, Kurikulum Tingkat Satuan Pendidikan (KTSP) untuk Madrasah Ibtidaiyah, Jakarta: Depag, 2006.

Departemen Agama RI., Kurikulum 2006, Pedoman Umum Pengembangan Silabus Madrasah Ibtidaiyah, Jakarta: Direktorat Jenderal Kelembagaan Agama Islam, 2006.

Djali, Psikologi Pendidikan, Jakarta. Bumi Aksara, 2008.

Harjanto, Perencanaan Pengajaran, Jakarta: PT. Bineka Cipta, 2001.

Hallen A., Bimbingan dan Konseling, Jakarta: Ciputat Press, 2002.

Khaeruddin, Ilmu Pendidikan Islam, Makassar : Yayasan Fabiah, 2002.

Muhaimin, Abd. Ghofir dan Nur Ali Rahman, Strategi Belajar Mengajar, Penerapan Dalam Pembelajaran Pendidikan Agama, Surabaya: CV. Citra Media, 1996.

Martinis Yamin, Profesionalisasi Guru dan Implementasi KTSP, Cet. IV, Jakarta: Gaung Persada Press, 2007.

Muhibbin Syah, Psikologi Pendidikan dengan Pendekatan Baru, Bandung: Rosdakarya, 1997.

Muhaimin, Dimensi-Dimensi Studi Islam, Surabaya: Karya Abditama, 1994. , Strategi Belajar Mengajar, Surabaya: Citra Media. 1996. 
Paradigma Pendidikan Islam, Bandung PT. Remaja Rosdakarya, 2002.

Muhibbin Syah, Psikologi Belajar, Jakarta : PT RajaGrafindo, 2003

Nana Syaodih Sukmadinata, Landasan Psikologis Proses Pendidikan, Bandung: Rosdakarya, 2005.

Nashar, Peranan Motivasi dan Kemampua awal dalam Kegiatan Pembelajaran, Jakarta: Delia press, 2004

Oemar Hamalik, Pendidikan Guru Berdasarkan Pendekatan Kompetensi, Bandung: Bumi Aksara, 2002. Kurikulum dan Pembelajaran, Jakarta: Bina Aksara, 1995.

Pemerintah RI,Undang-Undang Republik Indonesia No. 20 Tahun (2003). Sistem Pendidikan Nasional, Jakarta: Sinar Grafika: 2003.

Raisul Muttaqien, Active Learning 1001 Cara Belajar Siswa Aktif, Bandung: Nusamedia, 2006

Slameto, Belajar \& Faktor-Faktor Yang Mempengaruhinya, Jakarta: Rineka Cipta, 2003

Syaiful Bahri Djamarah, Psikologi Belajar, Jakarta : PT Rineka Cipta, 2002

Syukir, Dasar-dasar Strategi Dakwah Islami, Surabaya : Al-Ikhlas, 1983.

Tim Reality. Kamus Terbaru Bahasa Indonesia. Surabaya: Reality Publisher, 2008.

Tilaar, Beberapa Agenda Reformasi Pendidikan Nasional, Jakarta: Tera Indonesia, 2001.

Wina Sanjaya, Pembelajaran dalam Implementasi Kurikulum Berbasis Kompetensi, Jakarta: Kencana, 2006.

Umar Tirtarahardja dan S.L. La Sulo, Pengantar Pendidikan. Jakarta: Rineka Cipta, 2008. 